\title{
DETERMINANTS OF FISHERMEN INCOME in REGENCY OF WEST SERAM, MALUKU (Study in 3 Village of West Seram Regency)
}

\author{
Teddy Christianto Leasiwal \\ Lecturer at Economic Faculty \\ Pattimura University, Maluku \\ E-mail: imanuel tyo@yahoo.com
}

\begin{abstract}
Fishing prospects in West Serum regency from year to year more and more promising. It can be seen from the results of fisheries production is increasing. Fish production in 2009 increased by 1,828 tons or 9.5 percent from the previous year, with the potential of fish resources around 592,008.7 tons of new and utilized approximately 2.71 percent. This condition is caused by a lack of such infrastructure is supported by a fishing vessel, which is still dominated by boats and outboard motors around 99 percent. This may reflect that most fishermen in West Serum still relatively fishermen.In an effort to increase the income of fishermen, fishery busineses rurehe (pole And Line) in the District of West rurehe (pole And Line) in the District of West Serum District of West Serum belong in household scale industries (home industry) and the efforts of hereditary existed long ago. Based on the results of research in the field, until now rurehe industrial fisheries (pole and line) has yet to show the maximum results it can be seen from the amount of production obtained are still below the average in the amount of 482.8 tons / year. This condition is a portrait of the ability of the fishermen are still far in producing tuna in the District of West Serum District of West Serum, this is because in addition to lack of knowledge about ways of catching (experience at sea, the low level of education of fishermen, thus affecting the mindset of fishermen in the arrest, as well as the low level of wages of fishermen, lack of technologically which is used also affects tuna arrest method used in this study is a descriptive and quantitative methods. By using Data Analysis panel. The results showed the variables Age does not have an influence on the increase fishermen's income, variable production has a very strong influence on the increase in the income of fishermen. Technology variables also have a strong influence on the increase in revenue.
\end{abstract}

\section{Keywords: Income, Age, Production, Technology}

\section{INTRODUCTION}

Fishing prospects in West Seram regency from year to year more and more promising. It can be seen from the results of fisheries production is increasing. Fish production in 2009 Increased by 1,828 tons or 9.5 percent from the previous year, with the potential of fish resources around $592,008.7$ tons of new and utilized approximately 2.71 percent. This condition is the caused by a lack of such infrastructure is supported by a fishing vessel, the which is still dominated by boats and outboard motors around 99 percent. This may reflect that most fishermen in West Seram still quite traditional fishermen (Bps Maluku, 2010). Later in the districts of West Seram, fishery sub-sector 
Contributed sectoral very meaningful for agriculture, the which in 2010 listed the marine production (Results Capture) amounted to 3344.5 tons. This means that the fisheries sector is still providing a very large potency in creating output for the agricultural sector in the future.

In an effort to increase of the income of fishermen, businesses fisheries rurehe (pole And Line) in the District of West Seram District of West Seram belong in household scale industries (home industry) and the Efforts of hereditary existed long ago. Based on early research results in the field, until with the current fisheries industry rurehe (pole and line) has yet to show the maximum results it can be seen from the amount of production Obtained are still below the average in the amount of 482.8 tons / year.

This condition is a portrait of the ability of the fishermen are still far in producing tuna in the District of West Seram District of West Seram, this is Because in addition to lack of knowledge about ways of catching (experience at sea, the low level of education of fishermen, Thus affecting the mindset of fishermen in the arrest, as well as the low wage rate fishermen, low technologies of the which is used Also Affect catching tuna fish

As we all know that factor determinants of productivity of fishermen, as illustrated above, was instrumental in generating maximum production, as election use of fishing gear, methods of arrest, and so on, low level of education of fishermen were Also influential on the productivity of fishermen, and the which has a high school education, of course, have a different mindset with fishermen who do not have education., so that the work (at sea), already take into account and weigh all the benefits and risks for work (at sea), and the wage levels Also Affect the productivity of fishermen. Because when the fishermen wage rate increase is, will encourage fishermen to work more leverage in producing, vice versa.

This shows that the district has the potential fishery SBB large enough but a big potential have not-provided a strong influence on enhancing the local economy, especially the fishing community. Seen with income levels are still low.

\section{Research purposes}

The purpose of the study

1. For determinant to know the income of fishermen in SBB

2. How does the influence of The determinants of the income of fishermen in SBB 


\section{Benefits of research}

Benefits to be gained from this research:

1. For information or input material for the fishermen in the western part of the district spooky

2. As the material or information or inputs for local governments sinister western part

\section{THEORY AND HYPOTHESES}

\section{Production Function}

According Joesron and Suhartati (2003) production is the end result of a process or economic activity by using some of the inputs or input. In this sense it is understood that the production is to combine various input or inputs to produce outputs. Technical relationship between inputs and outputs in the form of equations, tables or graphs is the production function. Thus, the production function is an equation that indicates the maximum amount of output produced by a particular combination.

\section{Understanding Productivity}

In general, productivity is defined or defined as the ratio between output (output) by the income (input), while according to Ambar True Sulistiani and Rosidah (2003: 126) suggests that productivity is "Regarding the issue of the final outcome, ie how much the final results obtained in the production process, in this case the efficiency and effectiveness ".

There are several definitions of productivity, among others: According Hasibuan (2003: 105) "labor productivity is the ratio between the input output where the output should have added value and better workmanship techniques".

\section{Measurement of Labor Productivity}

Measurement of labor productivity according to a system of income of physical individuals / per person or per hour of work the widely accepted, but from the point of view / control daily, measurements are generally unsatisfactory, due to variations in the amount required to produce one 
unit of product different. Therefore, the measurement methods used labor time (hours, days or years). Expenditure converted into units of labor is usually defined as the amount of work that can be done in one hour by a trusted employee who works according to the standard implementation.

\section{Fishermen concept}

Fishermen are people who live on the livelihoods of marine products. In Indonesia, the fishermen usually live in coastal areas or coastal sea. The fishing community is a group of people whose livelihood marine and coastal living in villages or coastal (Sastrawidjaya, 2002). In terms of skills, although the fishermen work is hard work, but in general they have only modest skills. Most of them work as a fisherman is a profession that is scaled by the parents, not learned professionally. The social structure of the building, the fishing community consists of heterogeneous and homogeneous community.

\section{Revenue concept}

Fisherman income is the difference between revenue (TR) and all costs (TC). So Pd = TR TC. Acceptance of fishermen (TR) is obtained by multiplying the production obtained $(\mathrm{Y})$ with a selling price (Py). The cost of fishing is usually classified into two: a fixed cost (fixed cost) and variable costs (variable cost). Fixed costs (FC) is the cost of a relatively fixed amount and continue to be issued even though production gained a lot or a little. Variable costs (VC) are costs that are influenced by the size of the production obtained, for example, the cost for labor.

According Sukirno (2006) revenue is the amount of income received by a resident on his performance during a given period, whether daily, weekly, monthly or yearly. According Sobri (1999) disposable income is a type of income derived by a person who is ready to spend or consumed. The amount of disposable income that is earned income minus direct taxes (personal tax) as income tax. According to Milton Friedman's theory that people's income can be classified into two, namely the permanent income (permanent income) and income while (transitory income). 


\section{Fishermen and Factors Affecting Earnings}

Fishing communities is still a very interesting theme for discussion. Fishermen almost certainly discuss the issues that always comes up is that people are marginal, poor and be subject to exploitation rulers both economically and politically.

Fishermen who do arrest (aquaculture) in the sea and in a place that is still influenced the tides (Tarin, 2000). So when there is fishing in fish farming such as ponds, fish ponds, lakes, streams, not including fishermen. Furthermore, according to Tarin (2000), based on his opinion, the fishing can be divided into:

a. Fishermen or fishing remains full, the fishermen whose income is derived entirely from the fishery.

b. While the main fishermen, the fishermen most of its revenue comes from fisheries.

c. Additional sideline fishermen, the fishermen are a small part of its revenue comes from fisheries.

d. Seasonal fishermen, the people in certain seasons only active fishermen.

\section{Capital and Production Costs}

Capital there are two kinds, namely fixed capital and capital move. Fixed capital translates into production costs through deprecition costs and capital interest. Capital move directly into the production costs to the cost of the same premises capital value move.

Each production fisheries sub-sector was influenced by the production of working capital. The higher the working capital used per unit of effort it is expected that fish production will be better, is called the capital-intensive businesses or intensified.

Most of the capital owned by the fishermen used as production costs or operating costs, namely the provision of production inputs (means of production), operating costs and other costs in an effort fishing activities. Production costs or operating costs of fishermen are usually obtained from a group of fishermen, rich, owners of capital (toke), because of the relationship lending and borrowing money as working capital where the harvest season, the catch (production) of fishermen used to repay the entire loan debt, and the price level Fish is usually determined by the investors. 


\section{Previous Studies}

Sasmita (2006) analysis of the factors affecting operating income of fishermen in Asahan Knowing the factors affecting operating income of fishermen. Multiple regression independent variable working capital, time at sea and experience that can explain the variation of the dependent variable (fishermen operating revenues) of $60.7 \%$. Of the independent variables studied working capital and significant fishing 5\% while the labor force is significant at 10\% significant level. Equally examine the factors that affect the income of fishermen There is one factor that examined different. Namely, time

Harahap (2003) analysis of the problem of poverty and income level of traditional fishing beautiful fishing District of field Lubuhan Medan. Analyzing the problem of poverty and income levels of fishermen. independent variable capital investment / early, hours at sea, number of dependents, education and operational costs can be explained variance of the dependent variable (traditional fishing income) of $85 \%$. Of the independent variables studied investment capital / initial, hours at sea, operating costs significant at the level $\alpha=5 \%$, while the number of dependents is significant at $\alpha=10 \%$.

\section{Framework}

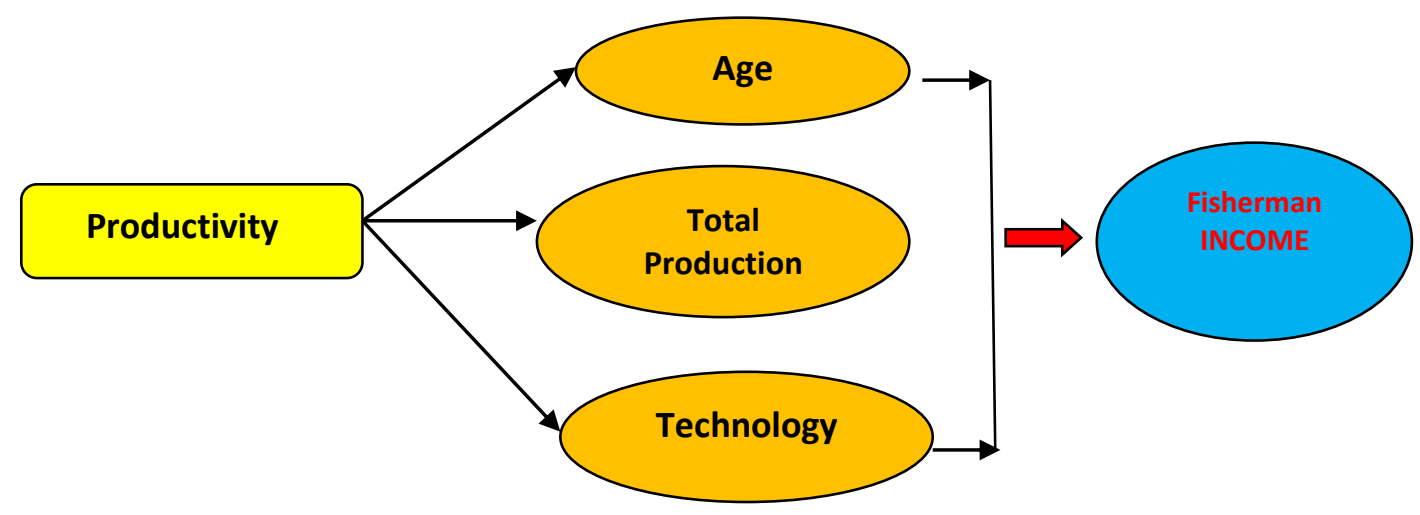




\section{Hypothesis}

1. Alleged that the age of the workforce affect positively on the income of fishermen in the following

2. Alleged that positively affect the production of the income of fishermen in the following

3. Alleged that the technology impact positively on the income of fishermen in the following

\section{RESEARCH METHODS}

The scope of research

The scope of this study includes analysis of factors that influence the fishermen income in West Seram regency.

\section{Object Research}

Which is the object of research is the fisheries sector of the agricultural sub-sector (fishermen in West Seram regency)

\section{Types and Sources of Data}

The type and source of research data is a crucial factor into consideration that determines the method of data collection. The data used in this study were divided into two types based on classification, namely: Primary Data and Secondary Data.

\section{Research methods}

The method used in this research is descriptive and quantitative methods. Descriptive method is a method in researching the status of human groups, an object, a condition, system, thought, or an event in the present (Moh.Nazir, 2005: 54). The purpose of descriptive research used to depict or describe a systematic, factual and accurate information on the facts, as well as the relationship between phenomena investigated. While the quantitative method is a method that emphasizes quantification in data collection and data analysis. 


\section{Data source}

This study uses secondary data in the form of time series (time series). The data collected is the data that have been published as follows:

\section{Data collection technique}

Data collected through observation of various secondary data needed from data BPS West Seram regency BPS Maluku Province and Regional Government of West Seram regency

\section{Analysis Method}

In this study will describe the influence of age, the amount of production and technology to operating income of fishermen in the western part of the district sinister formulated in function: $\boldsymbol{Y}=\boldsymbol{F}\left(\boldsymbol{X}_{1,} \boldsymbol{X}_{2}, \boldsymbol{X}_{3}\right.$

Where:

$$
\begin{aligned}
& \mathrm{Y}: \text { Income } \\
& \mathrm{X}_{1}: \text { Age } \\
& \mathrm{X}_{2}: \text { Production } \\
& \mathrm{X}_{3: \text { : Technology }}
\end{aligned}
$$

\section{Hypothesis Testing}

Testing this hypothesis cover simultaneous testing (test- $\mathrm{f}$ ), individual test (t-test), and testing the estimated provision ( $\mathrm{R}$ 2), which includes the classic assumption test multikolinearitas, heteroskedasitas, autocorrelation and normality.

\section{Statistic test}

\section{Testing The coefficient of determination $\left(\mathbf{R}^{2}\right)$}

The coefficient of determination refers to the ability of the independent variable $(\mathrm{X})$ in explaining the dependent variable $(\mathrm{Y})$. The coefficient of determination used to calculate how much variance and the dependent variable can be explained by variations in the independent variables. There is no definitive measure how much of $\mathrm{R}^{2}$ to say that a variable is right choice. If $\mathrm{R}{ }^{2}$ greater or 
close to 1, then the model more precise data. For survey data meaning is cross section, the data obtained from the respondents at the same time, then the value of $\mathrm{R}^{2}=0.3$ is good enough.

\section{Significant Simultaneous Testing (Test F-test statistics)}

This test is used to determine the influence of significant independent variable on the dependent variable. Where if $\mathrm{f}_{\text {count }}<\mathrm{f}_{\text {table, }}$ then $\mathrm{H}_{0}$ is accepted or independent variables together has no effect on the dependent variable (not significant) in other words the change in the dependent variable can not be explained by changes in the independent variable, where the level of significance used is $5 \%$.

\section{Classical Assumption Test}

\section{Test Multicollinearity}

Multicollinearity is a condition where there is a strong correlation between the independent variables $(\mathrm{X})$ are included in the formation of the linear regression model (Gujarati, 1991).

\section{Test Autocorrelation}

Autocorrelation is a condition where the variable disturbance in certain periods correlated with other variables in the period, in other words, disturbance variables are not random. As a result of the autocorrelation is a parameter that is estimated to be bias and its variants minimum, so inefficient, (Gujarati, 2003).

\section{Heteroscedasticitas Test}

This test aims to test whether the regression model occurred inequality variant of the residual one observation to another observation. Heteroscedasticitas occurs when disturbance variables do not have the same variance for all observations. Due to the heteroscedasticitas, OLS estimator is not biased but inefficient (Gujarati and Porter, 2003). The way to detect the presence or absence of heteroscedasticitas can be done by using white heteroscedasticity available in the program Eviews 6.0 .

\section{Normality Test}

Normality test is to see if the residual values are normally distributed or not. A good regression model is to have a residual value that is normally distributed. So normality test is not performed on each variable but the residual value. Plural common mistake is that the normality test performed on each variable. 


\section{RESULTS AND DISCUSSION}

\section{Classic Assumption Testing}

Classic assumption test deliberately used by the consideration that the estimation (t-test and test-F) will be valid or legitimate if it meets the classic assumption test. If the specification of multiple regression models that have been made in violation of classical assumptions, the results of t-test and F-test or the results of the econometric estimation of said bias and may lead to misinterpretation (Gujarati, 2009; Widarjono, 2010). Therefore, the classical assumption test was conducted to obtain regression parameter that is free of regression false (spurious regression) or regression false namely regression that describes the relationship between two or more variables that seem to be statistically significant, but in fact they are not, or are not as big as it appears in The resulting regression parameters.

The existence of spurious regression parameter in a research resulted in the interpretation of the resulting regression parameters can be misleading and in violation of the rules of econometrics (Gujarati, 2009; Widarjono, 2010). To get parameter regression BLUE (Best Linear Unbiased Estimator) the estimation result there should be no multicollinearity, autocorrelation and heteroskedasticity and must pass the test for normality

\section{Multicollinearity Test}

Multicollinearity problem is a situation where there is a correlation between independent variables with other independent variables. In this study will be used means used by Gujarati (2003) to detect the multicollinearity problem is to look at the correlation matrix (correlation between the independent variable).

\section{Autocorrelation Test}

Autocorrelation is one deviation from the classical assumptions indicated by the presence of serial correlation disturbance variable (error term) from time to time. There are several methods that are often used to detect or examine whether or not there is a problem of autocorrelation in the model. Such methods include the Durbin-Watson Test (Test DW) and Breusch-Godfrey Serial Correlation LM Test (Gujarati, 2003). In this study will use an easier method to detect the 
autocorrelation problem is the method Breusch-Godfrey Serial Correlation LM Test. The test results autocorrelation using Breusch-Godfrey Serial Correlation LM Test can be observed in the following table:

\begin{tabular}{rrrr}
\multicolumn{4}{c}{ Breusch-Godfrey Serial Correlation LM Test: } \\
\hline \hline F-statistic & 0.035199 & Prob. F (2,24) & 0.9655 \\
Obs * R-squared & 0.087739 & Prob. Chi-Square (2) & 0.9571 \\
\hline \hline
\end{tabular}

Description: Chi-Square table $\alpha=0: 05 ; \mathrm{df}(1)=3.8415$

Based on the test results in Table 1 shows that indicators $T * R$-squared is not statistically significant indicators calculated value $T * R$-square $d$ of $0.608345<$ chi-squared tables $(\alpha=0.05 ; \mathrm{df}(1)=3,8415)$ or observed probability value $T^{*} R$-squared of $0.435>0.05(\alpha=5 \%)$, which is to reject $H_{a}$ or declare that the regression model used does not contain the problem of autocorrelation.

\section{Result Estimation}

Based on the results processed using eviews 6, to obtain the model estimates and estimated as follows:

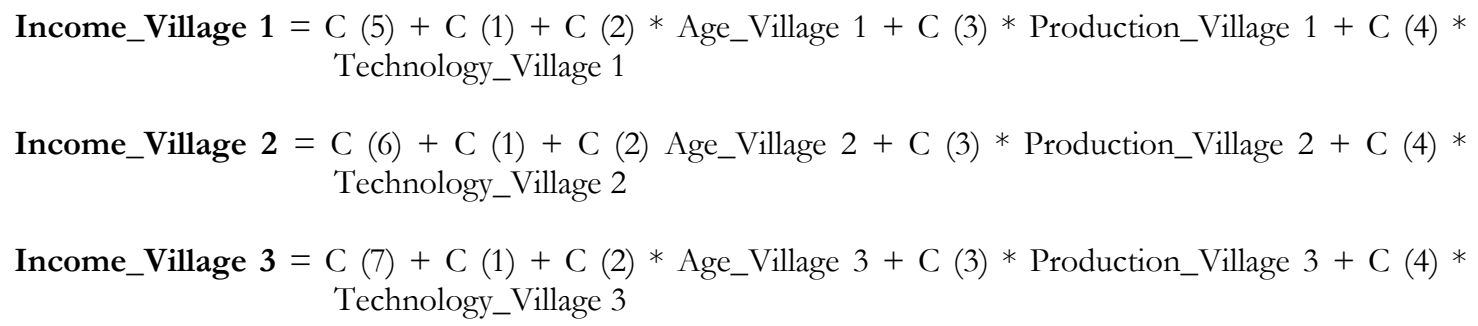

Multiple regression estimation results in Partial

\section{VILLAGE 1}

\begin{tabular}{ccccc}
\multicolumn{5}{c}{ Estimated results } \\
Variable & Coefficient & Std. Error & t-Statistic & Prob. \\
C & -12285.29 & 27630.12 & -0.444634 & 0.6606 \\
Age & 1791.900 & 748.1920 & 2.394974 & 0.0248 \\
Producion & 8049.438 & 1773.242 & 4.539390 & 0.0001 \\
Technology & -16954.86 & 18295.31 & -0.926733 & 0.3633
\end{tabular}

Analysis Village 1 . In the first village, the age variable with a probability level of 0.0248 and variable production with a probability level of 0.0001 has a significant and positive effect on the income of fishermen in the village 1 (hypothesis proven). While the technology variables do not have a significant effect. This shows that the income of fishermen in the village 1, is largely 
determined by the productive age and the amount of production. So the higher production and more productive age who work as fishermen, the public revenues will increase.

VILLAGE 2

\begin{tabular}{crrrr}
\multicolumn{5}{c}{ Estimated results } \\
Variable & Coefficient & Std. Error & t-Statistic & Prob. \\
C & 32246.45 & 14338.88 & 2.248882 & 0.0340 \\
Age & 227.5406 & 333.8413 & 0.681583 & 0.5020 \\
Producion & 5696.913 & 454.2768 & 12.54062 & 0.0000 \\
Technology & -10893.60 & 7682.598 & -1.417957 & 0.1691
\end{tabular}

Analysis of the Village 2. In the second village, variable production with a probability level of 0.0000 has a significant and positive effect on the income of fishermen in the village of 2 (the hypothesis is proven). While the age variable and variable technology does not have a significant effect. This shows that the income of fishermen in the village 2 , is determined by the amount of production. So the higher the production of fishing then people's income will increase.

\section{VILLAGE 3}

Estimated results

$\begin{array}{crrrr}\text { Variable } & \text { Coefficient } & \text { Std. Error } & \text { t-Statistic } & \text { Prob. } \\ \text { C } & 33705.10 & 19153.87 & 1.759701 & 0.0912 \\ \text { Age } & 255.2125 & 560.7244 & 0.455148 & 0.6531 \\ \text { Producion } & 6269.612 & 213.1665 & 29.41181 & 0.0000 \\ \text { Technology } & -17017.99 & 5076.813 & -3.352101 & 0.0027\end{array}$

Analysis Village 3. In the third village, variable production with a probability level of 0.0000 and 0.0027 technology with a probability level has a significant and positive effect on the income of fishermen in the village 3 (hypothesis proven). While the variable age has no significant influence. This shows that the income of fishermen in the village 3 , is determined by $n$ number of production and technology. So the higher production and better and more frequent use of technology, people's income will increase.

\section{Results of Multiple Regression Estimation in Simultaneous SBB}

$\begin{array}{crrrc}\text { Variable } & \text { Coefficient } & \text { Std. Error } & \text { t-Statistic } & \text { Prob. } \\ \text { C } & 31631.64 & 11493.38 & 2.752162 & 0.0111 \\ \text { Age } & 447.5491 & 315.4507 & 1.418761 & 0.1688 \\ \text { Producion } & 6341.275 & 257.3728 & 24.63848 & 0.0000 \\ \text { Technology } & -15072.78 & 5918.911 & -2.546546 & 0.0177\end{array}$




\section{District analysis SBB}

At SBB district, Technology and Variable Variable production has a significant and positive effect on the income of fishermen in the district SBB (the hypothesis is proven). While the variable age has no significant influence. This suggests that an opinion of fishermen in the district SBB, is determined by the use of technology in the capture and production quantities. So the higher production and more often dn high technology used, the public revenues will increase.

\section{Conclusion}

1) In the district $\mathrm{SBB}$, variable Age does not have an influence on the increase in the income of fishermen, that is to say here that the productive age engaged in the fisheries sector, especially as fishermen catch, did not have a significant impact for increased productivity and incomes of fishermen, so whatever age entry in this sector are not take effect for increasing revenue.

2) At SBB district, variable production has a very strong influence on the increase in the income of fishermen. Therefore it needs to be maintained even increase production should continue, driven due to an increase in production, there will be increase in revenue in the SBB fishermen. Thus the need to maintain the SBB local governments and encourage the continuity of the production of fishing catch, by providing various programs or other support so that the production is maintained.

3) At SBB district, variable technology also has a strong influence on the increase in revenue. Enhancement and use of technology in the district of fishermen at SBB will give effect to the level of income. But in general it can be said that the three determinants such as age, production and technology has influence on the increase in the income of fishermen in each village. So the government needs to take action to encourage efforts to increase production, use of technology and the age productive in managing and utilizing the catch. 


\section{Suggestion}

1. For that we need the government's role in empowering the community through programs that can improve the productivity of fishermen so as to increase the revenue that will ultimately improve their welfare.

2. The need for additional training and technology by governments to fishing communities in order to increase production, which in turn will raise the income of fishing communities.

\section{BIBLIOGRAPHY}

Supreme Gunanto, EY 2011. Analysis of Poverty and Income Families in District Fishermen Case Wedung Demak district in Central Java Indonesia. Journal of Economic Dynamics Development, Volume 1, No. 1, 50-58.

Almatsier. 2006. Principles of Nutrition. Gramedia Pustaka Utama. Jakarta.

Amalia, DR 2012. Analysis of Household Income men Ship (ABK) Members Fishermen Fishing Village Unit Cooperatives (KUD) Mina Jaya in the Southern District of Teluk Betung Bandar Lampung. Essay. University of Lampung. Lampung

Imron, M. 2003 "Poverty in Fishermen Society" in Journal of society and culture. PMB LIPI. Jalaluddin.2002. Technology Education. King Grafindo Persada. Jakarta.

Mulyadi, S. 2003. Economic Human Resource Development Perspective. PT. King Grafindo Persada. Jakarta.

Notoatmodjo Soekidjo, 2003. Human Resources Development (Revised Edition), Rineka Reserved. Jakarta

Sasmita, 2006. Analysis of Factors Affecting Enterprises Fishermen in Asahan, Thesis S2. PPS USU, Medan. http://www.slideshare.net/nurimans/09-e00282. (downloaded October 3, 2013)

Michael P. Todaro and Stephen C. Smith, 2003, the Economic Development in the Third World, the eighth edition, grants, Jakarta.

Zulfikar, 2002. Analysis System for the results of the Labour Earnings Against Fishermen in Deli Serdang, North Sumatra, thesis S1, EP USU, Medan. http://www.slideshare.net/nurimans/09-e00282 (downloaded October 3, 2013) 